\title{
Volcanism-induced karst landforms and speleogenesis, in the Ankarana Plateau (Madagascar). Hypothesis and preliminary research
}

\author{
Eric Gilli ${ }^{*}$ \\ ${ }^{1}$ Geography Department, University Paris 8, France
}

\begin{abstract}
The Ankarana is a limestone plateau in the northern part of Madagascar, where a cave system, more than $120 \mathrm{~km}$ long, has been explored. The plateau is bordered by volcanoes and is cut across by several canyons. An analysis of surface landforms and caves suggests that the karst genesis was probably initiated by volcanism beneath an impervious cover. Volcanic bulging and magma intrusions may have favored a basalt-limestone assimilation process and metamorphism. The ascent of deep volcanic fluids $\left(\mathrm{CO}_{2}\right.$ and $\left.\mathrm{SO}_{2}\right)$ from magma degassing and from limestone metamorphism, may explain the speleogenesis. Once denuded, the karst evolved classically, but the selective erosion of metamorphosed rocks (more likely to be weathered than pure limestone), resulted in the creation of unusual landforms such as canyons and large circular basins.
\end{abstract}

Keywords: $\quad$ karst landforms; volcanism; hypogenic speleogenesis; Madagascar

Received 22 December 2013; Revised 9 March 2014; Accepted 6 May 2014

\begin{abstract}
Citation: Gilli E., 2014. Volcanism-induced karst landforms and speleogenesis, in the Ankarana plateau (Madagascar). Hypothesis and preliminary research. International Journal of Speleology, 43 (3), 283-293. Tampa, FL (USA) ISSN 0392-6672 http://dx.doi.org/10.5038/1827-806X.43.3.5
\end{abstract}

\section{INTRODUCTION}

Among the various karst areas of Madagascar (Mahafaly, Bemaraha, Namoroka, Narinda and Mikoboka), the Ankarana limestone plateau in Ambilobe (Madagascar) is one of the most important and the most accessible. A cave network, more than one hundred kilometers long, was explored there. Due to the presence of volcanoes and lava flows around the plateau, it is possible that karst landforms and speleogenesis were induced by volcanism or magmatism. This paper presents a few observations and compilations that support this hypothesis. It suffers from the lack of detailed field and laboratory data and must be considered as a preliminary research in view to trigger further investigations.

The main features of the geology and geomorphology were defined by de Saint Ours (1958). The geological map (Ambilobe-Betsiaka U32-V32 sheet) was published in 1963, by the Geological Survey of Madagascar under the direction of Besairie (1973). Various geological and geo-morphological studies were performed by Battistini (1965) and Rossi (1973, 1974). The latter published an important work on the Extreme-North of Madagascar (Rossi, 1980) in which he details the Ankarana geomorphology. Recent work was done to characterize the tsingy
(Veress et al., 2009; Salomon, 2003) but few studies have been done on the genesis of the Ankarana caves and landforms.

\section{PRESENTATION OF THE AREA}

\section{Geography}

The Ankarana is located in the province of Diana, in the northernmost part of Madagascar, about $80 \mathrm{~km}$ SW of Antsiranana and $30 \mathrm{~km} \mathrm{NW}$ of Ambilobe (Fig. 1).

It is a tabular limestone block, about $35 \mathrm{~km}$ long, with a maximum width of $10 \mathrm{~km}$ and a general NESW orientation. The surface elevation of the plateau ranges from $300 \mathrm{~m}$ to the north, to a few tens of meters at its southern end. It is bordered to the NW by an escarpment, the Ankarana Wall, that reaches a height of $200 \mathrm{~m}$ (Fig. 2).

The plateau is subdivided by a series of canyons and corridors, roughly perpendicular to the Ankarana Wall. The Ankarana contains a huge network of caves, that are often very large. The tsingy (a type of pinnacle karst) forms the plateau surface (Veress et al., 2009; Salomon, 2009) (Fig. 3).

The plateau is divided into three units, from north to south (Fig. 4):

- the North Ankarana that forms a massive block, intersected by deep and narrow canyons, 


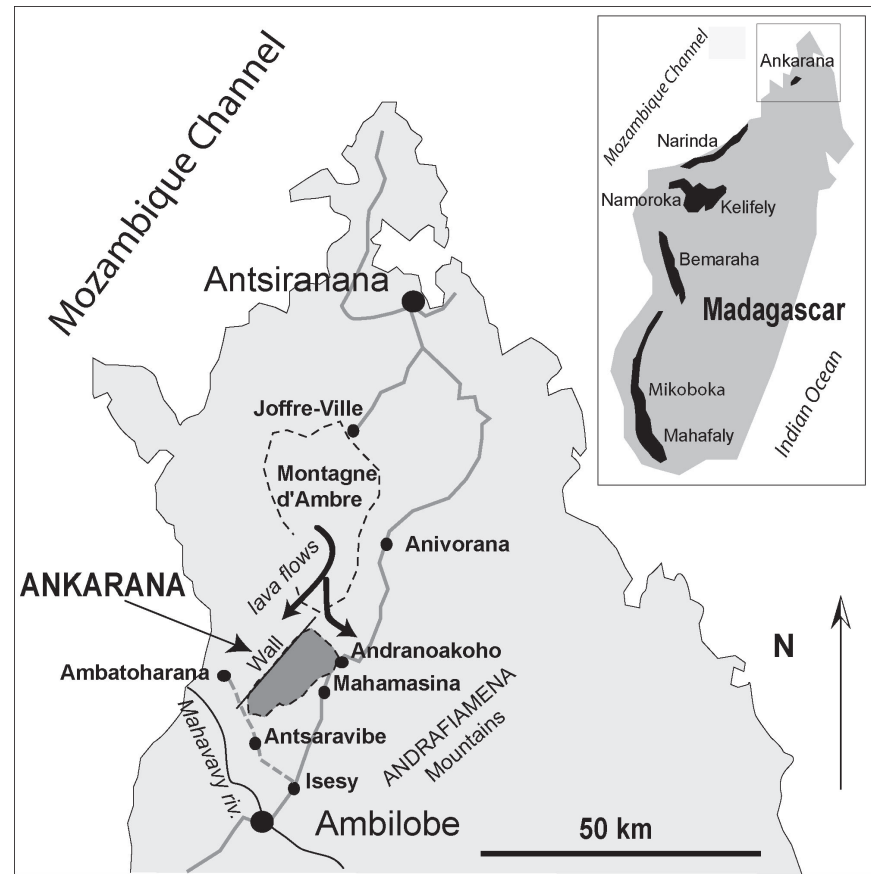

Fig. 1. Location of the Ankarana Plateau and the main karst areas of Madagascar.

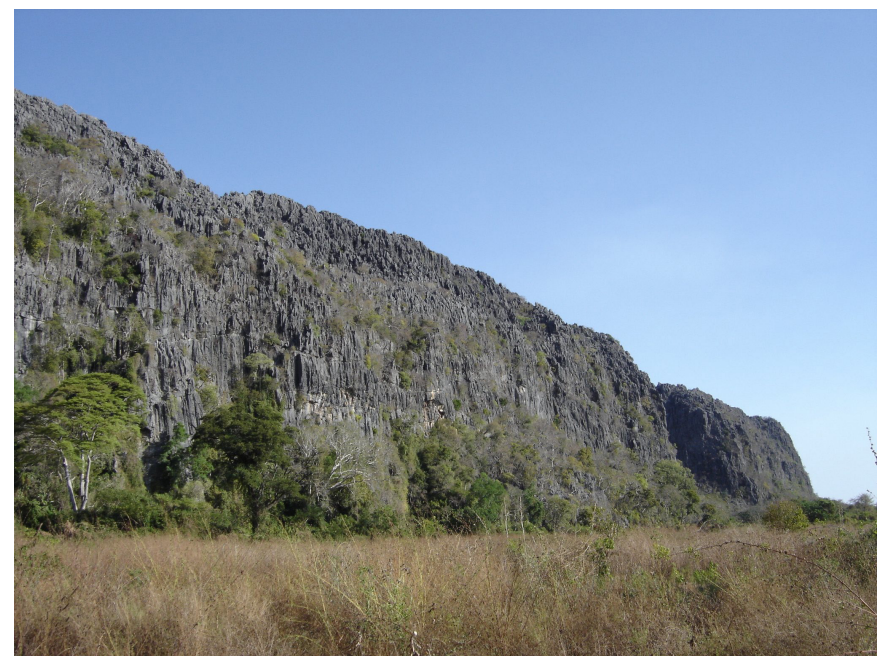

Fig. 2. The Ankarana Wall, the fault escarpment that limits the plateau to the west.

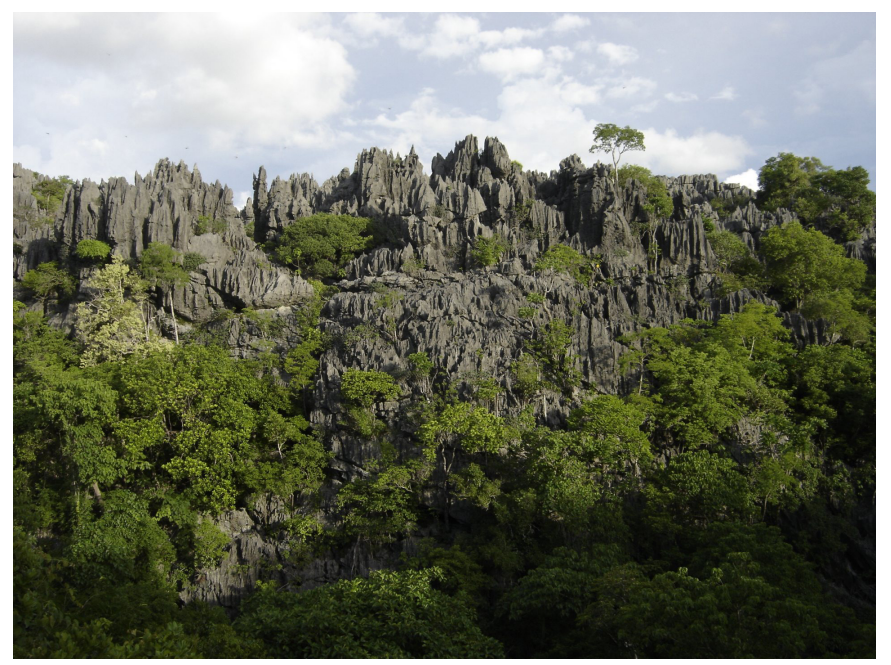

Fig. 3. The Ankarana tsingy in the Southern buttes. Similar karst features are observed in the whole limestone area.
- the three Mananjeba Buttes - they are separated from the previous unit by the enlargement of a major canyon.

- the Southern Buttes - at the southern end of the massif, they form a set of five small isolated massifs.

The climate is tropical, with a pronounced dry season in winter, from May to October. The temperature varies from $24.5^{\circ} \mathrm{C}$ to $28.3^{\circ} \mathrm{C}$ (Rossi, 1980).

The surrounding impervious formations collect rainfall and feed several rivers that disappear upon contact with the limestone (Fig. 4). The five major rivers in the region are, from north to south :

- the Andranotsisiloha (out of map), which sinks partially into impenetrable boulders in the extreme northern part of the massif;

- the Besaboba, which disappears completely into a vast shaft, on the eastern part of the massif. During the rainy season, this shaft is totally flooded and the Besaboba continues running southward;

- at the southwestern end of the North Ankarana area, two karstic springs, the Ankara spring and the Resurgence Maurice, feed the Antenanankarana River that runs toward west, to the sea. The discharge during the dry season is about $1.5 \mathrm{~m}^{3} \mathrm{~s}^{-1}$.

To the south, the two main rivers are the Mananjeba and the North Mahavavy. These two rivers run through the vast Ambilobe alluvial plain. They divide into several, more or less parallel, branches. They have dismantled the southernmost extremity

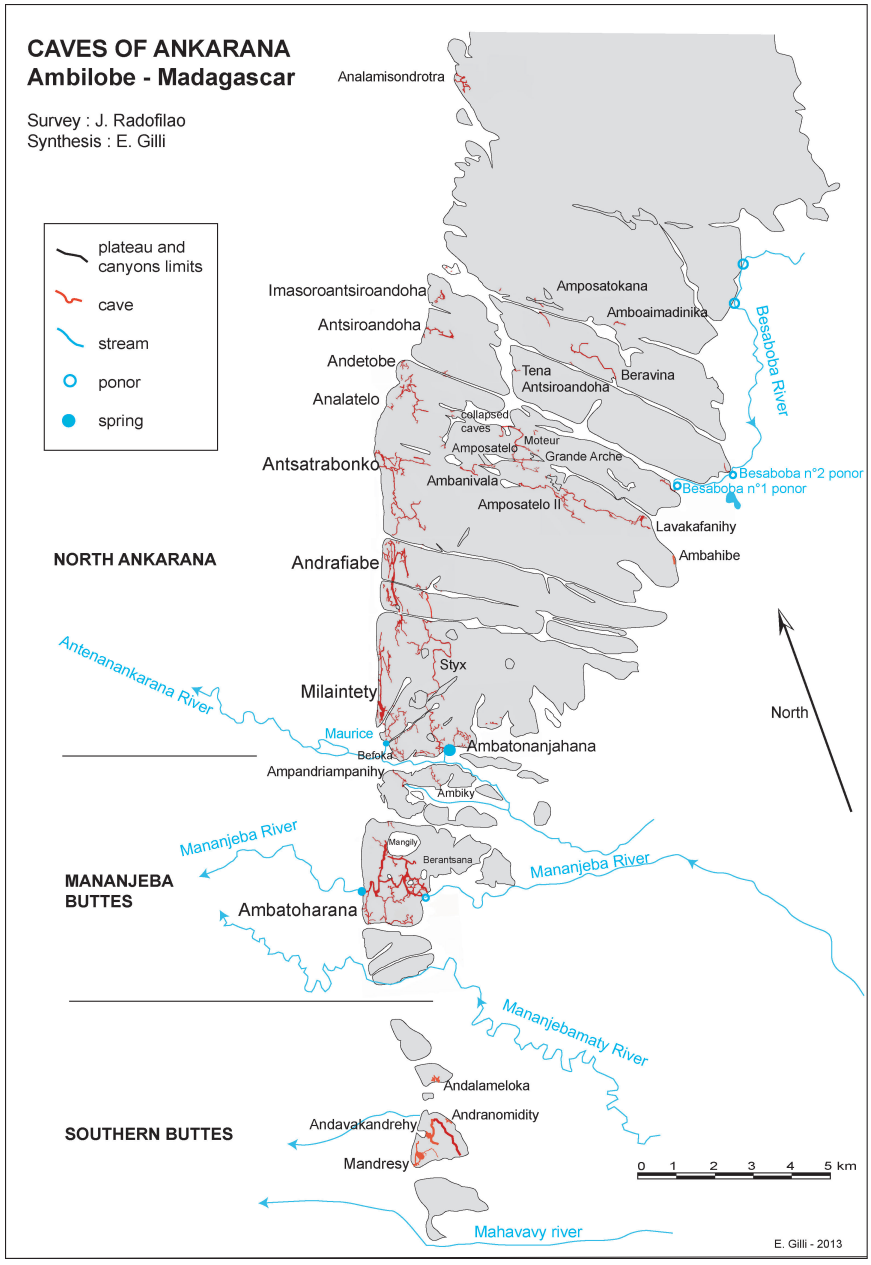

Fig. 4. Ankarana caves and river networks (from unpublished J. Radofilao's surveys). 
of the plateau, which is gradually buried below the alluvium. The Mananjeba River is divided into three branches, whose main one runs for 2700 meters, through a limestone butte, in Ambatoharana cave. The Mahavavy is the main stream in this region. It borders the southernmost butte and, at one point, forms a picturesque ox-bow lake.

\section{Geology}

The plateau is a NE-SW vast syncline in Jurassic epicontinental limestone. The dips do not exceed $10^{\circ}$ (Figs. 5, 6).

The geological section made by Saint-Ours (1958) and Rossi (1980) shows the following sequence, from bottom to top (Fig. 6):

- an impervious Liassic marly substratum,

- Bajocian and Bathonian limestone highly karstified,

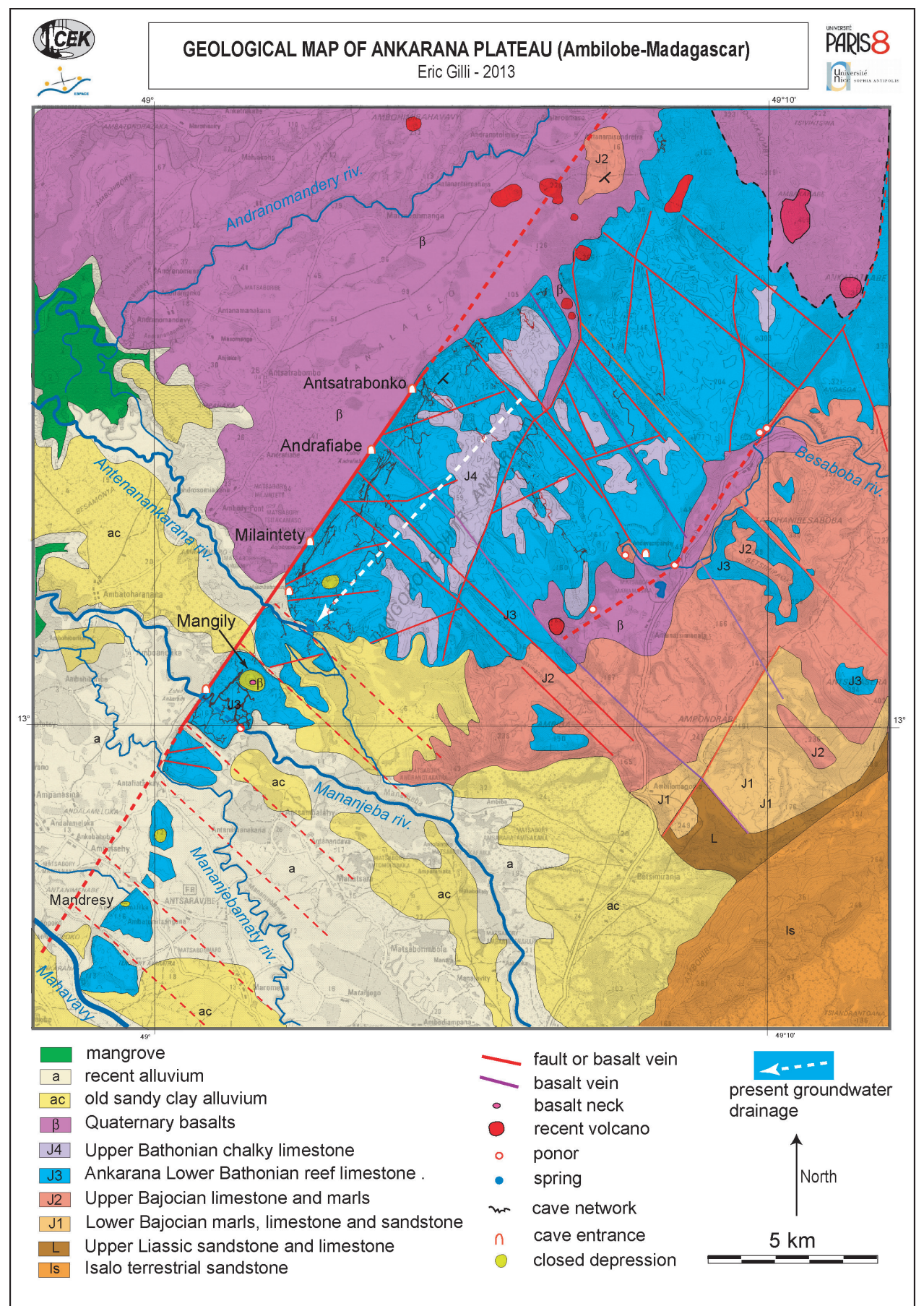

Fig. 5. Geological map of the Ankarana Plateau and its $120 \mathrm{~km}$ long cave network. The largest caves are located near volcanic features (veins or volcanoes) and close to the Ankarana Wall, which is likely a main basalt dike.
- more or less sandy chalk, which forms residual mounds observed above the Ankarana.

The Cretaceous seems to be absent in this area, although marine sedimentation was continuous until the Lower Cretaceous. It was probably completely stripped away by erosion. The Ankarana block behaved as a rigid slab and it recorded all movements in the region. These movements induced several directions of fractures:

- the Ankarana Wall, which marks the western edge of the plateau, is a major NE-SW fault scarp, whose throw probably exceeds $400 \mathrm{~m}$. To the east, in the Besaboba valley, a similar but smaller fault limits the plateau;

- the Couloirs are aligned on a NW-SE direction. A $\mathrm{N}-\mathrm{S}$ direction is also observed, but it appears to be less important;

- $\quad$ in the central zone, a $\mathrm{N}^{\circ} 5^{\circ}$ to $30^{\circ}$ reverse fault can be seen (Karche, 1972; Rossi, 1980) (Figs. 5, 6).

The density and orientation of the fractures and the presence of several volcanoes (Figs. 5, 7) suggest an uplift and a volcanic bulge of the whole area.

In Madagascar volcanism was active during two distinct periods (Besairie, 1973):

- During the separation of Madagascar and Greater India from Africa, late Jurassic to mid-Cretaceous fissure type volcanic events. The dikes, that are present on the western and eastern coasts, are frequently oriented NW-SE (Mahoney et al., 1991).

- Tertiary to present-day alkaline volcanism. It is mainly observed in the center of Madagascar, in the Itasy or Tsaratanana areas, or in the Montagne d'Ambre, in the extreme-north of the island, (Rossi, 1980).

In the studied area, several volcanic features are encountered and the presence of both ages is possible. To the north, the Montagne d'Ambre volcano is a Miocene to Holocene system (Besairie, 1973, Rossi, 1980, Cucciniello et al., 2011). Its basalt completely covers the northern part of the Ankarana Plateau. It flows into the main topographic depressions of the eastern part (Besaboba Valley) and runs alongside the Ankarana Wall in the western part, where it penetrates into a few canyons (Forest Canyon). Small strombolian cones are present on both sides of 


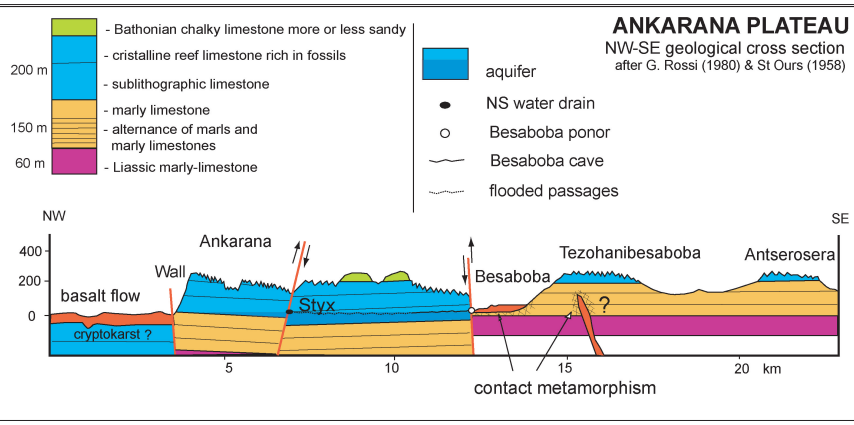

Fig. 6. Schematic cross-section of the NW-SE Ankarana (after Rossi, 1980).

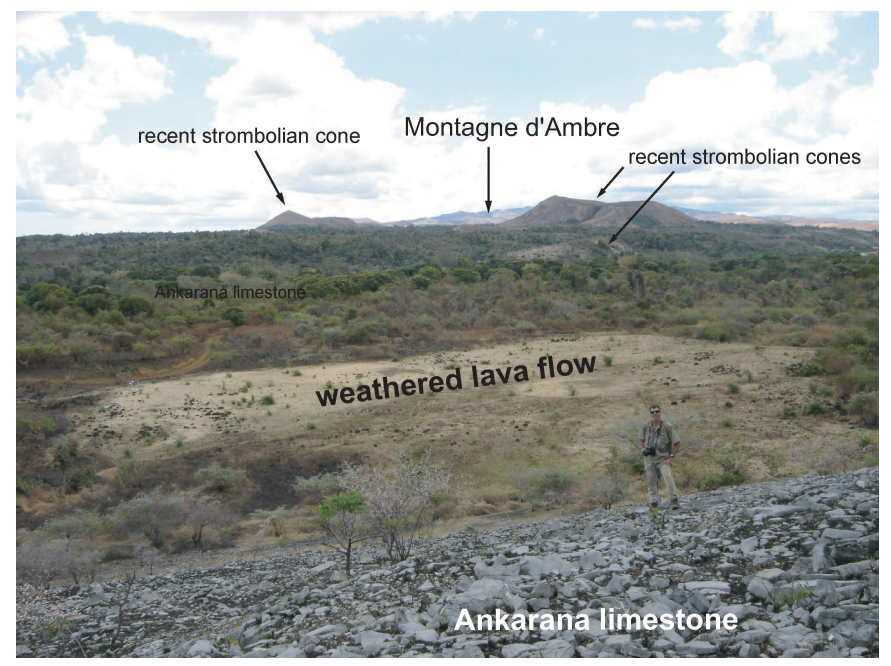

Fig. 7. Foreground to background: Ankarana limestone, weathered basalt flow, recent Strombolian cones, Montagne d'Ambre volcano (in the clouds).

the plateau (Fig. 7). The poorly eroded flanks indicate a Holocene age for the younger ones. To the east, dikes were observed that could be older (Fig. 5).

\section{Cave network and present karst hydrogeology}

More than $120 \mathrm{~km}$ of caves have been explored since the 1960s (Radofilao, 1977; Courbon \& Chabert, 1986) (Fig. 4). Most of these explorations were undertaken by the local caver Jean Radofilao and by French groups (Gilli et al., 1981; Peyre et al., 1983, 1984).

The cave dimensions vary from very small crawl tubes, to corridors that reach $50 \mathrm{~m}$ width in the Mandresy or Andrafiabe caves. Several long cave systems (Andrafiabe, Milaintey, Antsatrabonko) run NE-SW, parallel to the Ankarana Wall. Most of the explored passages are active or semi-active and situated close to the elevation of the rock wall base. Sumps are frequent and some sections show navigable underground rivers, the most notable being the $4 \mathrm{~km}$ long Styx River. The longest cave of the Ankarana is Ambatoharanana, which totals more than $18 \mathrm{~km}$. It is a maze that extends south of the Mangily basin, in the Mananjeba butte (Fig. 8).

The water input to the plateau is three-fold: rainfall, several ponors and the two previously described large streams that pass through the plateau in the southern zone (Fig. 9).

To the north, a vast system drains the limestone plateau towards the SW, to the main source of the river Antenanankarana (or Ankara) and its tributary, the Maurice resurgence. De Saint Ours (1959) suggested

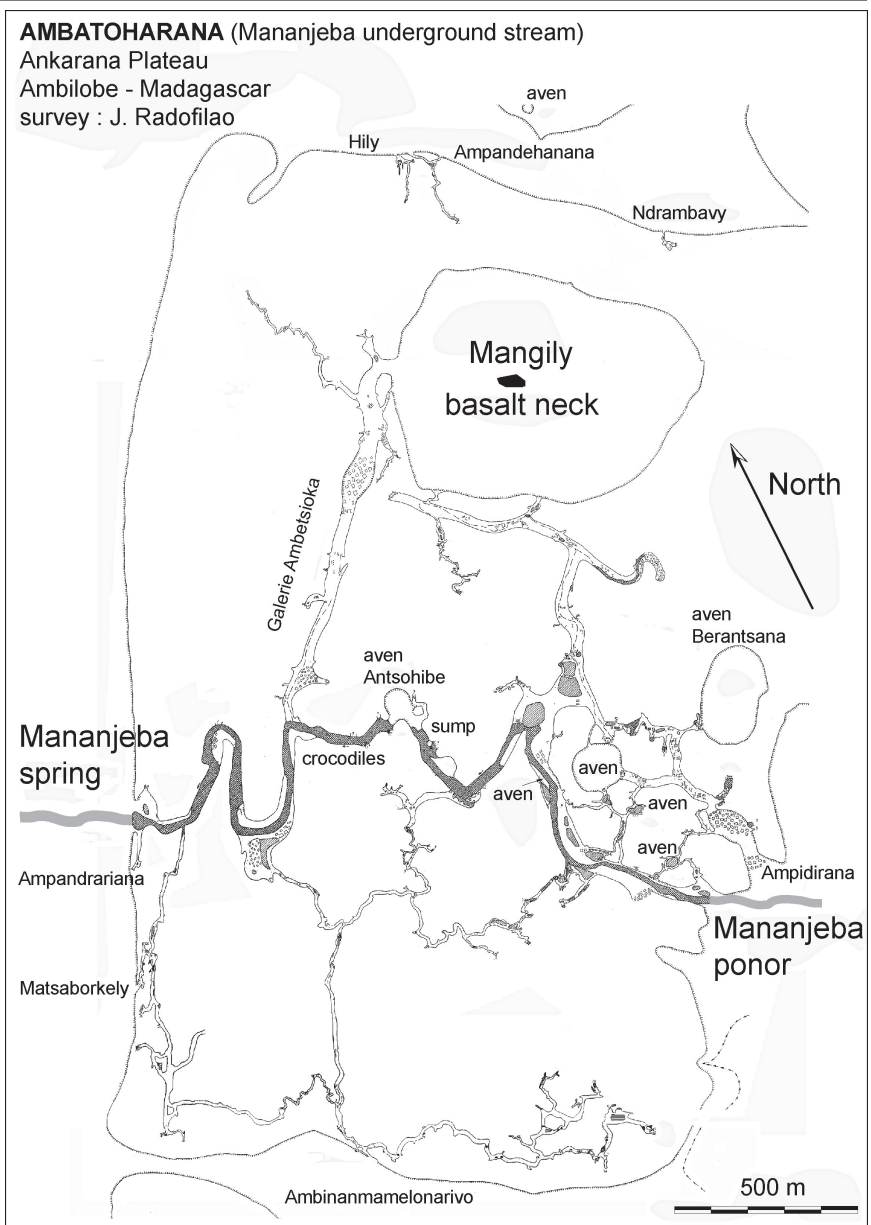

Fig. 8. Ambatoharana, the longest cave of Ankarana. Note the Mangily closed depression that one can only reach using cave passages.

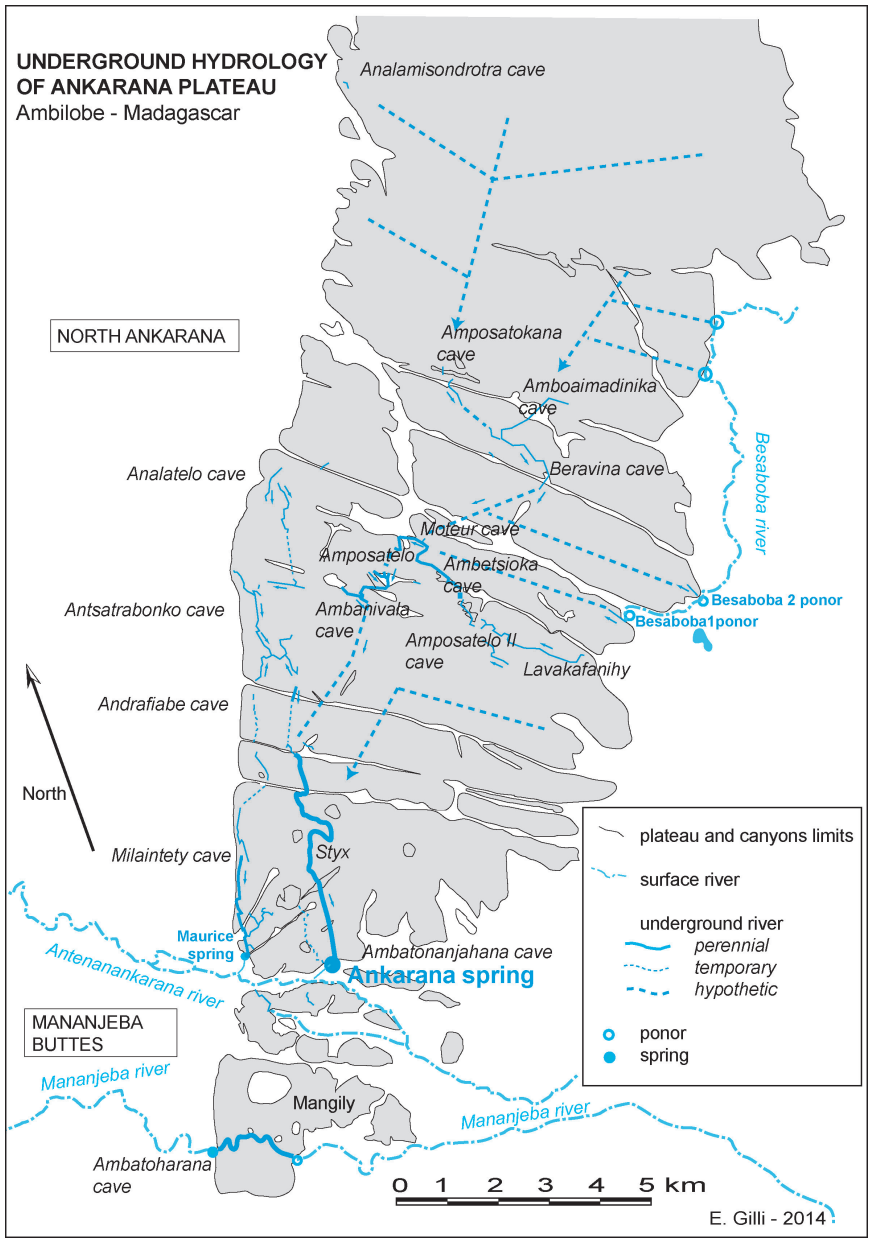

Fig. 9. North Ankarana and Mananjeba buttes underground water circulations. 
the existence of a main drain, the Collecteur, that drives the infiltrated water towards the Antenanankarana springs, along the synclinal axis of the plateau. The Collecteur was discovered in 1984 (Peyre et al., 1984). This underground river was so large that a motorboat was used during exploration. Most of the underground tributaries join this 'master' system. The E-W canyons do not form an obstacle to the drainage and are crossed by the underground rivers.

To the south, several buttes form independent water systems. Their watersheds are reduced, but both streams (Mananjeba and Mahavavy) completely flood the limestone plateau and can inject large quantities of water transporting significant amount of sand and clay. This results in intense karstification and causes the deposition of thick layers of sediments.

The karst hydrologic system can be vertically divided into several parts :

- $\quad$ inactive galleries with no perennial runoff;

- a network of galleries with portions of large rivers that feed the perennial springs;

- a deep aquifer that is probably drained towards the alluvial aquifers of the Mananjeba and Mahavavy rivers, as suggested by the inspection of water wells located west of the Ankarana. The water table in these wells is a few meters below the land surface.

The sea shore is nearby $(12 \mathrm{~km})$ and the global sea level drop, during glacial periods, made it possible the valley incisions and the deepening of the karst aquifer.

\section{HYPOTHESIS ON THE KARST GENESIS}

\section{Particularity of the Ankarana Plateau}

In addition to the tsingy, that are present in most of the karst area in Madagascar, some karst features are specific from the Ankarana : the Couloirs, deep an narrow canyons that dissect the plateau, and the closed depressions that are present in several parts of Northern Ankarana and Mananjeba butte. Their genesis is not well explained.

The Couloirs extend toward east, perpendicular to the Wall. They often crossover the plateau but sometimes they end suddenly, like a pocket valley. Rossi (1980) propose either a karst dissolution origin, or a tectonic one, where Couloirs are micro-grabens (Fig. 10).

Several large closed depressions are also present on the plateau. The most important one, the Mangily, is a 800 x $500 \mathrm{~m}$ large circular basin with vertical walls, that perforates the Mananjeba butte (Fig. 8). Rossi

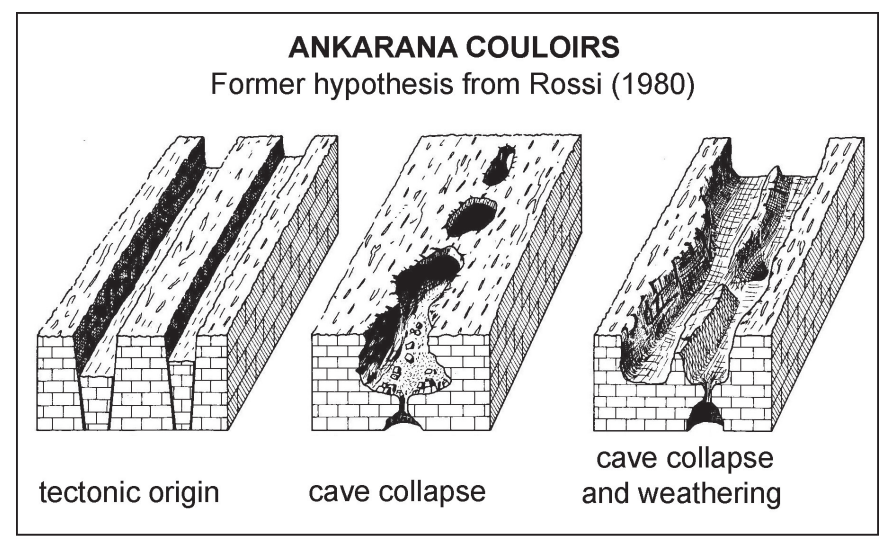

Fig. 10. Ankarana couloirs genetic hypothesis from Rossi (1980)
(1980) considered a volcano-tectonic origin for it and Wilson (1987) instead supposed it was a huge collapsed underground chamber.

\section{Possible role of volcanism in surface landforms modeling}

During a field trip in 2005, a small basalt hill, previously reported by Rossi, was observed in the center of the depression (Fig. 11). It reinforces the hypothesis of an origin induced by volcanic processes for this karstic formation. The total absence of blocks, except at the foot of the rock walls, invalidates a tectonic or a collapse origin.

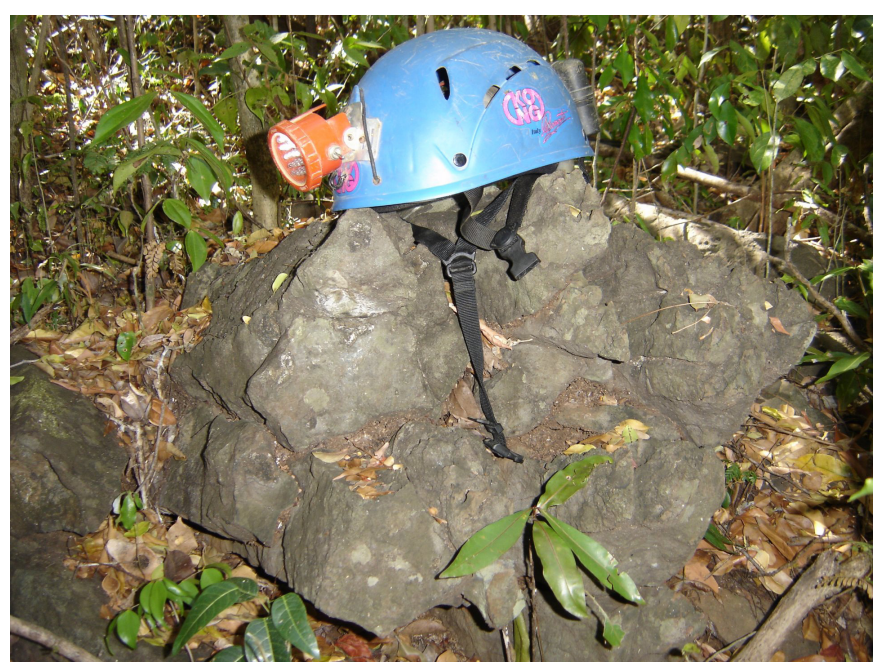

Fig. 11. Horizontal basalt prisms, at the top of the neck, in the center of Mangily basin. Their orientation indicates a vertical ascent of the basalt.

A review of Google Earth satellite images shows that the main Couloirs are prolonged by lineaments that extend several kilometers east of the Ankarana (Fig. 5). A field trip made it possible to confirm that these lineaments are basalt dikes. They are easy to observe east of the Antsiranana road, in a recently denuded area, where they intrude into the limestone or the marly-limestone series (Fig. 12).

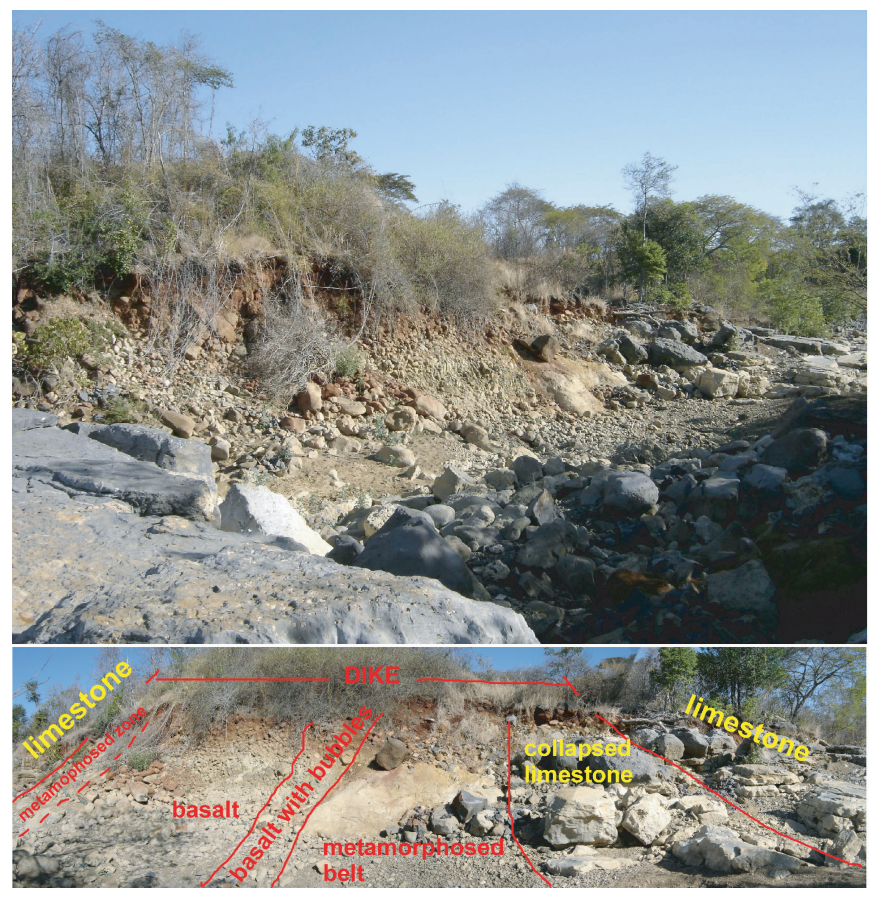

Fig. 12. Pre-corridor with basalt dike and metamorphosed area. The recently denuded limestone is poorly altered (top - general view; bottom - detail). 
A basalt extrusion can be observed, which caused contact metamorphism, with a clear limit, between the limestone and the metamorphosed band. Differential erosion forms a vertical limestone wall, close to which the limestone metamorphosed zone quickly dissolves, while the basalt is affected by an intense spheroidal weathering process (Fig. 12-bottom). This is a juvenile form of the canyon whose older aspect can be observed to the west, in the nearby Ankarana Plateau. This observation, which also concerns a second lineamentcanyon system, could be extended to the other Couloirs, but more field work is necessary.

Volcanism is therefore an important phenomenon and I propose a morphogenetic process, combining volcanism, corrosion, metamorphism and selective erosion, to explain the genesis of both features.

\section{HYPOTHESIS ON THE GENESIS OF COULOIRS AND CLOSED DEPRESSIONS}

\section{Discussion on the action of basalt on limestone}

When lava flows on the rock surface, thermal exchanges with air and water result in rapid cooling and the lava alters the limestone to a small extent. For instance, in Ambohimalaza (3 km SW from Mahamasina), on the eastern side of Ankarana, the basalt fossilizes karst pinnacles (Rossi, 1980).

However, deep beneath the earth's surface, cooling is limited by the low thermal conduction of the limestone (thermal conductivity is $5.5 \times 10^{-7} \mathrm{~m}^{2} / \mathrm{s}$ ). Metamorphism is then responsible for the recrystallization of calcite (Kjølle, 2000) or for the formation of marbles, if the pressure is high enough and if silicates are present. The size and nature of the metamorphosed aureole are a function of the depth and temperature of the igneous material. It may be reduced to a few centimeters, as observed in the Buchan caves limestone (Barker \& Bone, 1995) or be a few kilometers wide in plutonic areas.

Modeling for a $5.3 \mathrm{~m}$ thick dike in Killala Bay (Ireland) shows that temperatures in the limestone, a few meters from the dike, remain very high $\left(500^{\circ} \mathrm{C}\right)$ for several months (Joesten \& Van Horn, 1999).

A first hypothesis is that very close to the basalt, in a low pressure context, the heat causes the limestone to calcinate, releasing carbon dioxide and turning into calcium oxide (quicklime) at $900^{\circ} \mathrm{C}$. When combined with water it can form calcium hydroxide (slaked lime).

$$
\begin{aligned}
& \mathrm{CaCO}_{3}--->\mathrm{CO}_{2}(\mathrm{~g})+\mathrm{CaO} \text { (quicklime) } \\
& \mathrm{CaO}+\mathrm{H}_{2} \mathrm{O}--->\mathrm{Ca}(\mathrm{OH})_{2} \text { (slaked lime) }
\end{aligned}
$$

The solubility of calcium oxide and calcium hydroxide (1650 and $1590 \mathrm{mg} \cdot \mathrm{L}^{-1}$, respectively) is much higher than that of pure limestone $\left(15 \mathrm{mg} . \mathrm{L}^{-1}\right.$ or $250 \mathrm{mg} . \mathrm{L}^{-1}$ in its bicarbonate form) and this could explain the more intense weathering in limestone. However there are no examples of $\mathrm{CaO}$ or $\mathrm{Ca}(\mathrm{OH})_{2}$ outcrops in nature.

A second hypothesis is based on the existence of a basalt-limestone assimilation process, where basalt is enriched in $\mathrm{CaO}$ while limestone loses $\mathrm{CO}_{2}$ and gains $\mathrm{SiO}_{2}$. Laboratory experiments on basalt and limestone show that the decomposition and degassing of $\mathrm{CaCO}_{3}$ may start at $600{ }^{\circ} \mathrm{C}$ making melting between magma and $\mathrm{CaO}$ possible (Deegan et al., 2010). Thus basalt may partially "digest" limestone. This process forms different types of rocks depending on the temperature, the pressure, and the respective proportions of $\mathrm{CaO}$, $\mathrm{SiO}_{2}$, and $\mathrm{H}_{2} \mathrm{O}$ (Baker \& Black, 1980; Iacono-Marziano et al., 2007). This basalt-limestone assimilation process, combined with hydrothermal activity, makes the basalt more susceptible to erosion (McGreevy, 1982). It may also transform calcite in silicates that are more likely to weather than pure calcite. Thus the whole area affected by the transformation (basalt and metamorphosed belt) becomes more susceptible to erosion than the surrounding limestone.

\section{Hypothesis on the canyons genesis (Fig. 13)}

The narrow dikes and their metamorphosed zones do not constitute a hydrogeological barrier and can easily be crossed by underground water flows, an occurrence that has been observed by cavers (e.g. in Analamisondrotra Cave). In most large caves, such as the Andrafiabe or the Milaintety caves, the main galleries are cut by canyons. This proves that the canyons are younger than the caves, while the basalt dikes are older. The dikes could be of Cenozoic age, like Montagne d'Ambre volcanism, but their NW-SE orientation also supports a Cretaceous age (Besairie, 1973, Mahoney et al., 1991).

Below the surface, the karst system evolves with cave networks that can pass through narrow veins of basalt and metamorphosed areas. They may or may not be eroded, depending on the direction of the water circulations. The flow direction (Fig. 9) depends on the geometry of the impermeable substratum and on the elevation of the springs. When the hydraulic gradient causes the groundwater to flow north-south, perpendicular to the veins, it simply passes through, whereas when it establishes in an E-W direction, the water is driven by the dikes. It can alter the basalt and the metamorphosed belt and enlarge them.

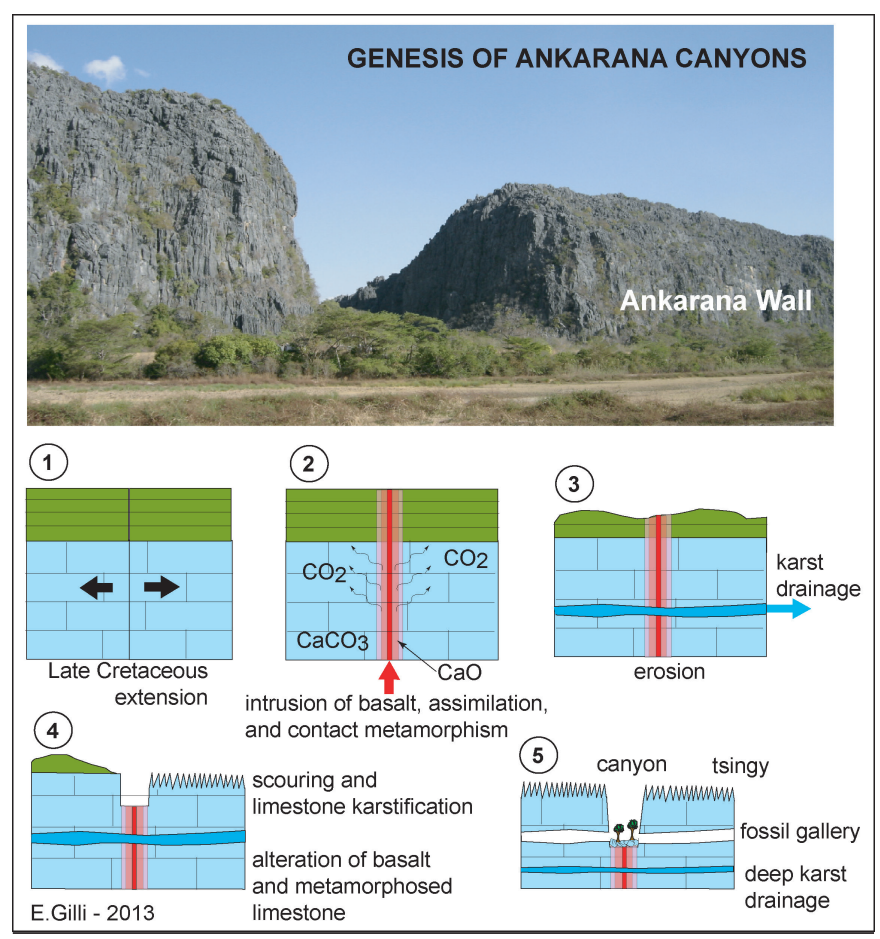

Fig. 13. Hypothetical genesis of the Ankarana canyons. 
At the surface, when the limestone and basalt veins are covered by a layer of marls, they are protected from weathering. But when the cover becomes thin enough, active karstification begins, beneath the cover. Then, when the cover is totally eroded, the tsingy develops intensely. This also promotes the alteration of the basalt dikes, which evolve rapidly, becoming larger and deeper. In most cases, the weathered rocks are completely leached away and limestone blocks, collapsing from the walls, mask the bedrock. Thus it is impossible to observe the remnants of the dikes. However, occasionally, some elements of basalt are visible among the tsingy, or on the canyon walls ( $\mathrm{J}$. Radofilao, pers. comm.).

This phenomenon may be more or less widespread, depending on the extent of the metamorphosed area. But it also depends on the nature of the dikes, which range from several-kilometer-long basalt veins to ones only a few tens of meters long. This allows a variety of canyon shapes, ranging from simple fracture enlargements to vast canyons with vertical walls. This also explains why some canyons are continuous while other ones are interrupted (Rossi, 1980).

As long as the alteration does not reach the karst substratum, deep water circulation is still possible below the canyon floors, as proven by the presence of a single main spring, south of the plateau. The largest canyons and those that have since long lost their impermeable cover, can broaden and deepen, until reaching the Liassic substrate. This creates a complete isolation of the karst system and individualizes limestone buttes, such as those observed in the south of the plateau, where the Ankarana Plateau is gradually buried beneath the Mahavavy alluvium.

\section{Hypothesis on the closed depressions genesis (Fig. 14)}

The Mangily closed depression may be the result of a similar mechanism. Its central basalt neck shows basalt prisms orientation that confirms a vertical ascent of the lava (Fig. 11). An hypothesis is that during the neck intrusion, the heat metamorphosed the limestone or highly transformed its porosity and the basalt was enriched in $\mathrm{CaO}$. The limestone and the aureole started being affected by a hypogenic process of dissolution or ghost-rock karstification (Dubois et

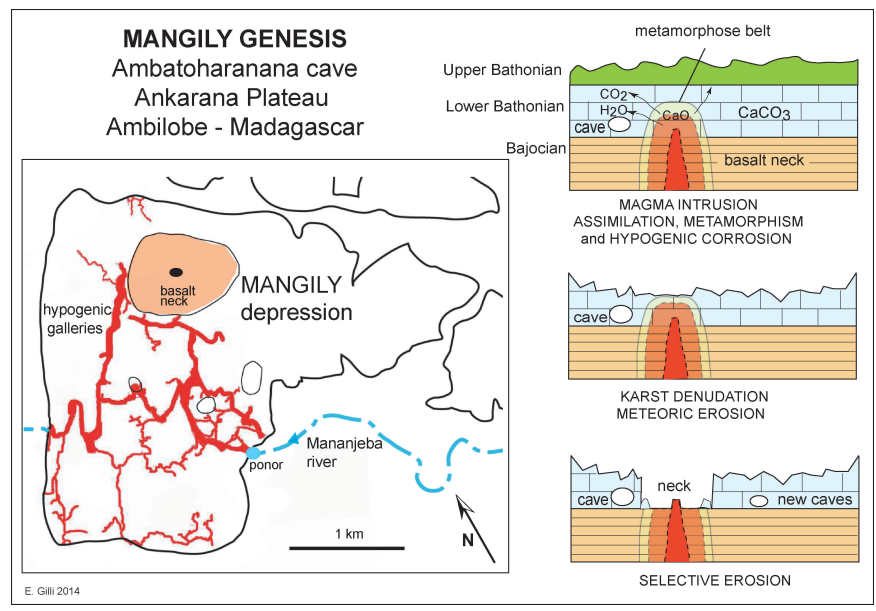

Fig. 14. Hypothetical genesis of the Mangily basin in the Ankarana Plateau. al., 2014) below the overlying cover, by the $\mathrm{CO}_{2}$ and $\mathrm{H}_{2} \mathrm{O}$ issued from the degassing magma or the metamorphic reactions. Then, when the plateau started being denuded, the whole metamorphic aureole, the transformed basalt or the ghost-rock alterites were quickly dissolved, or washed away, by meteoric water. The residue could be evacuated by the connected cave system, as huge galleries are present south to the Mangily (Fig. 8).

I have no proof on the presence of basalt in the center of the Ankarana other large closed depressions. Therefore, during different war periods in the $19^{\text {th }}$ century, Antankarana people and cattle found refuge in these depressions that are only accessible by the caves. They used to stay there for long periods and cultivated in the closed depressions (Decary \& Kiener, 1970) which reinforces the probability of a basalt soil present there. Future studies will have to focus on this part.

\section{ANKARANA SPELEOGENESIS}

\section{Volcanism and speleogenesis}

This mechanism, which may explains the Ankarana surface landforms, could be extended to the genesis of part of the cave network. The role of volcanism in the speleogenesis was suggested to explain greater karstification in the Apennines (Central Italy), near volcanic edifices. The role of magmatic $\mathrm{CO}_{2}, \mathrm{SO}_{2}$ or $\mathrm{H}_{2} \mathrm{~S}$, first discussed by Demangeot (1963), is supported by cave observations in Italy (Galdenzi, 2009; Menichetti, 2009).

In Turkey, the formation of the obruks, a type of mega-doline, is explained by heat and by a considerable amount of carbon dioxide supplied by a magmatic source (Bayari et al., 2009).

In Mexico the deep Zatacon system is also related to a hypogenic mechanism related to volcanism (Gary \& Sharp, 2006).

In addition to the generation of fluids, volcanism also produces constraints and distortions that fracture the limestone and guide the erosion process (Salomon, 2009).

\section{Hypothesis on the Ankarana speleogenesis}

The Ankarana Wall is a major normal fault, which puts the Mid-Jurassic limestone into contact with more recent impermeable series (Jurassic and Cretaceous marls and marly-limestone). Before the erosion of these impermeable series, the Ankarana Wall had been a hydrologic boundary for karstic groundwater.

A primitive network of large caves and mazes is established in the Northern Ankarana. It is parallel to the Ankarana Wall (e.g., Andrafiabe, Milaintety, and Antsatrabonko). The Southern Buttes also have remnants of large galleries, which were more or less parallel to the Wall. This confirms the importance of this main fault in driving the Ankarana speleogenesis. However the position and size of this primitive network are difficult to understand. It is located close to the Wall, far from the synclinal axis where the groundwater is now drained (Fig. 9). Moreover, the presence of Upper Jurassic residual mounds, at the surface of the plateau, shows that the karst was previously covered 
by impervious rocks. Thus it was not a suitable place for water infiltration and limestone dissolution. Our hypothesis is that a hypogenic process took place with fluids $\left(\mathrm{CO}_{2}, \mathrm{H}_{2} \mathrm{O}, \mathrm{H}_{2} \mathrm{~S}\right.$, and $\left.\mathrm{SO}_{2}\right)$ coming from the underlying magma.

Terrestrial magmas may contain significant concentrations of $\mathrm{CO}_{2}$ and $\mathrm{H}_{2} \mathrm{O}$ from a few \%o to about $10 \%$ in weight for subduction zones (Wallace, 2005). These fluids significantly alter the physical and chemical properties of magmas. This affects fundamental geological processes such as partial melting, ascent, eruption, degassing and crystallization of magmas. Their role in the transport and redistribution of metals, in hydrothermal ore bodies, is well known, and their possible impact on speleogenesis has occasionally been proposed (Gunn, 2004; Gary \& Sharp, 2006; Klimchouk \& Ford, 2009).

These high pressure magmatic fluids can degas when the magma approaches the surface. Maximum degassing occurs during the eruption, but degassing can also occur before the lava reaches the surface (Lesne et al., 2011). For example, for the continuous degassing of the Stromboli active volcano, quantities are estimated between 6,000 and 12,000 tons/day of gas, primarily $\mathrm{H}_{2} \mathrm{O}, \mathrm{CO}_{2}$, and $\mathrm{SO}_{2}$ (Allard et al., 1994). On Tenerife Island (Spain), in the Canaries rift zone, the total diffused $\mathrm{CO}_{2}$ values, measured on a $72 \mathrm{~km}^{2}$ area, were estimated to 146 tons/day. The peak values are spatially correlated with volcanic alignments, suggesting a structural control on the mechanism of diffuse degassing. (Martin et al., 2003). Limestone assimilation by magma is also an important source of volcanic $\mathrm{CO}_{2}$ (Iacono-Marziano \& Gaillard, 2006) but active volcanoes are not the only source of deep $\mathrm{CO}_{2}$; large quantities are also observed in quiet volcanic areas or in tectonically active areas, which produce non-volcanic Earth degassing $\mathrm{CO}_{2}$ (Cardellini et al., 2011).

Volcanism in limestone regions can therefore produce large quantities of water acidified by $\mathrm{CO}_{2}$, which will promote the dissolution of carbonates. It is therefore very likely that the different phases experienced by the Ankarana volcanism were accompanied by fluid circulation leading to the dissolution of limestone in a hypogenic speleogenesis mechanism.

Some hypogenic caves develop in the atmosphere at or above the water table, mainly by condensation and corrosion, due to the combination of thermal convection, and sulfuric and carbonic corrosion (Audra et al., 2009; Audra et al., 2010). If oxygen and water are present, the degassing of $\mathrm{SO}_{2}$ promotes the production of sulfuric acid, which reacts with the limestone to produce gypsum (Hill, 1987; Ford, 1989; Klimchouk, 1997).

$$
\begin{gathered}
2 \mathrm{SO}_{2}(\mathrm{~g})+\mathrm{O}_{2}(\mathrm{~g})+2 \mathrm{H}_{2} \mathrm{O}(\mathrm{l})--->2 \mathrm{H}_{2} \mathrm{SO}_{4}(\mathrm{aq}) \\
\mathrm{CaCO}_{3}+\mathrm{H}_{2} \mathrm{SO}_{4}+\mathrm{H}_{2} \mathrm{O}--->\mathrm{CaSO}_{4} \cdot 2 \mathrm{H}_{2} \mathrm{O}+\mathrm{CO}_{2} .
\end{gathered}
$$

$\mathrm{H}_{2} \mathrm{~S}$ may also be involved in similar reactions to produce $\mathrm{H}_{2} \mathrm{SO}_{4}$ (Hill, 1987).

In the Ankarana, preliminary observations, which still need to be confirmed by more accurate field research, suggest a hypogenic hypothesis for the old north-south network that extends close to the Ankarana Wall :

- gypsum was encountered on the floor, in the upper levels of the Milaintety cave and beneath the alluvium of the Mandresy cave (Fig. 15);

- yellow formations, that are probably rich in sulfur, are also visible in Mandresy;

- solution rills that could be related to convection were observed on the walls of the Andrafiabe cave (Figs. 16, 17).

\section{Hypothesis on the late evolution of the karst system}

The karst system evolved both vertically and horizontally, depending on the denudation of the Bathonian limestone that allows the infiltration of rainfall and the development of a classical epigenic karstification keyed to discontinuities. Underground circulation enlarged the discontinuities, and partially

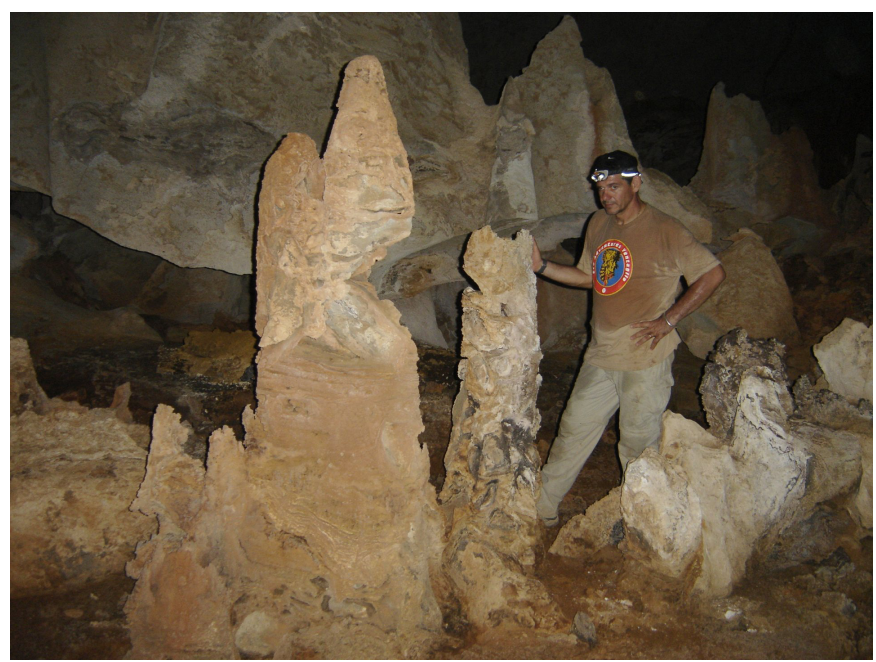

Fig. 15. Underground gypsum breccia pinnacle in Mandresy Cave. This formation was found in a fossil part of the cave. Pinnacles are limestone breccia with gypsum cement or massive gypsum.

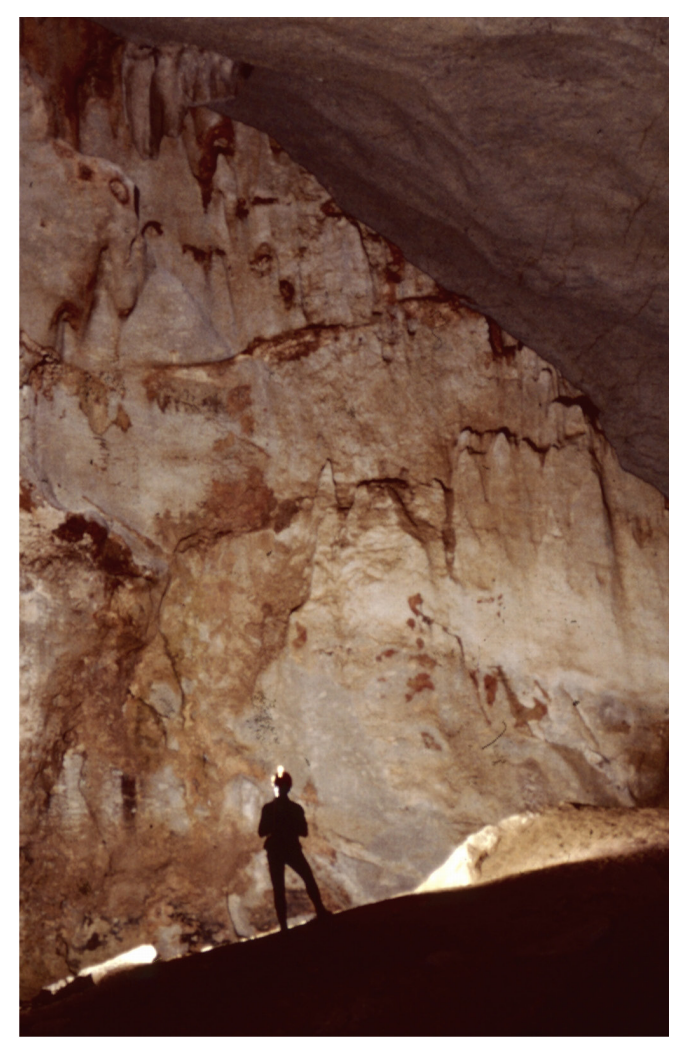

Fig.16. Wall solution rills in the Andrafiabe Cave. 


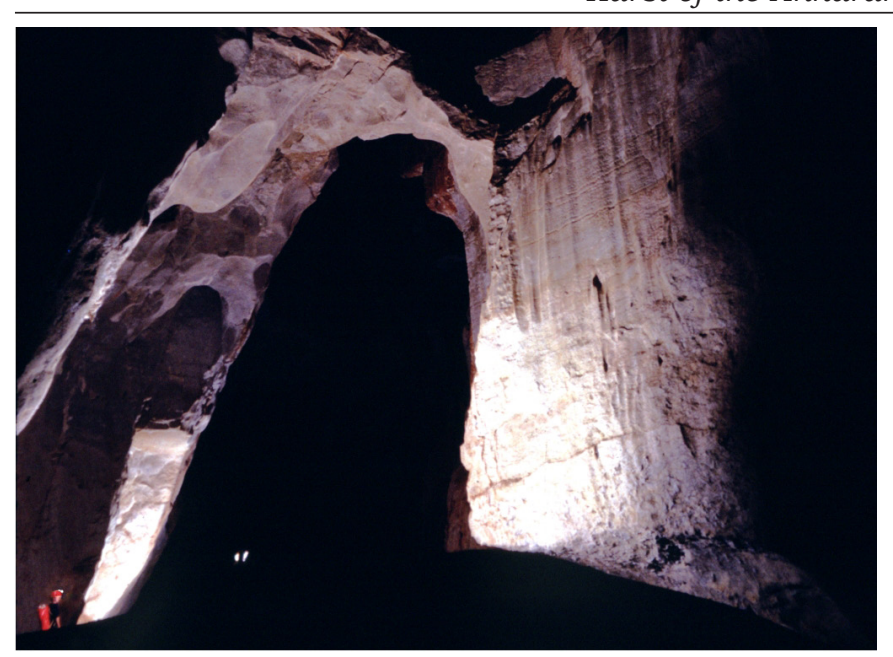

Fig. 17. Wall solution rills in the Andrafiabe Cave (see up right).

reused the previous hypogenic networks, while outside, the differential erosion in metamorphic zones resulted in the birth of canyons and closed basins.

This evolution gradually led to the individualization of the southernmost parts of the plateau, which are now drained by their own hydrological systems.

In the Southern Buttes, which are flooded yearly by the Mananjeba and Mahavavy rivers, a significant amount of water circulates into the limestone. The water transports abrasive particles that come from the Isalo sandstone. This resulted in the birth of underground mazes and spectacular erosional features in the eastern part of the buttes.

\section{Possible age of the karst}

The NW-SE orientation of the dikes suggests a Cretaceous age (Besairie, 1973; Mahoney et al., 1991). I propose the following chronology (Fig. 18):

- Late Cretaceous (pre-rifting phase): bulging and intense fracturing of the Ankarana area; first basalt intrusions within the limestone block. Deep confined hypogenic karstification.

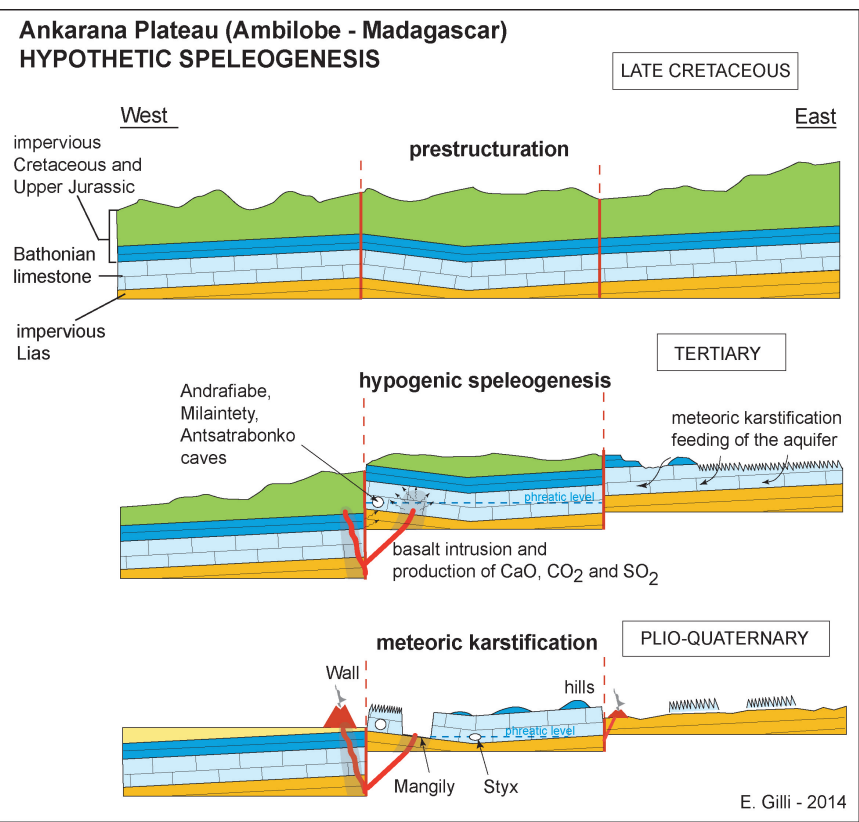

Fig. 18. Hypothetical speleogenesis of the Ankarana system. The karst first evolved hypogenically when volcanism was active and when the limestone was covered with an impermeable layer of marls. Surface denudation then made possible weathering and epigenic karst evolution.
- Tertiary: partial denudation of limestone and early meteoric karstification; individualization of the buttes in the southern part of the plateau.

- Plio-Quaternary: denudation of the limestone: effusive volcanism from Montagne d'Ambre and invasion of landforms by basalt. Complete individualization of the Southern Buttes and northward migration of the Ankarana River's source to its present position.

\section{CONCLUSION}

In addition to its well developed surface landforms (tsingy) and its varied wildlife, the Ankarana Plateau offers very interesting underground patterns and should be better studied from the geologic and geomorphologic points of view. The present paper is a preliminary one that needs to be completed by future studies.

The plateau is surrounded by lava flows and some small strombolian cones are present above the limestone. Even if a significant amount of work is necessary to better characterize the mechanisms that produce karst landforms and caves, there is no doubt about the fact that volcanism played an important role in the origin of the Ankarana karst landforms. The presence of basalt dikes or necks in some canyons and the largest closed depression is certain, but their existence remains to be investigated in other similar places, in order to confirm a common origin for the same landforms. An accurate identification of rocks and minerals, that are present in the metamorphic belts, is also necessary to better understand the basalt-limestone assimilation process.

The main large galleries are in an abnormal position, parallel to the Wall, or to the Mangily in its southern part. This position, which is not concordant with a normal water drainage, suggests an hypogenic origin for the cave system. In addition to the abnormal cave network geometry, gypsum and underground solutions rills that were observed in some caves, support that hypothesis. Future research will have to focus on several features that are described by Audra et al. (2010) or Klimchouk (2004), to characterize hypogenic caves, such as mineralization, cupolas, box works, and large crystals. For instance, the presence of large transparent calcite rhombohedra was reported in the Andrafiabe Cave (SaintOurs, 1959) and should be confirmed, and the origin of the underground solution rills observed on cave walls (Figs. $16 \& 17$ ) remains to be studied. New surveys of the main caves and their upper levels are also necessary to better characterize the relations between the different cave levels and the water table. Indeed, most of the cave systems are horizontal ones, and few data are available concerning the elevation of the galleries. It is therefore impossible to characterize the different levels and see if the presumed hypogenic speleogenesis occurred at depth or at the piezometric surface.

If the hypothesis of a speleogenesis related to the presence of significant fluid circulation at depth, caused by degassing magma or metamorphic zones, is confirmed, this could open interesting research directions. Indeed, this means that such mechanism allows for an increase in the global porosity of covered limestone blocks where volcanism or active tectonics are present. This opens 
interesting perspectives for researching capacitive zones in confined limestone blocks that were not weathered, and could therefore be good reservoirs for oil or water (Gilli, 2011).

\section{ACKNOWLEDGEMENTS}

Thanks are due to J. Radofilao who has explored and surveyed most Ankarana caves and provided maps and observations. Teams members F. Tessier, J.-Ch. Peyre, D. Bessaguet, P. Gilli, and G. Tennevin for their help during the field trips. C. Fandel who improved the French to English translation. P. Williams, B.P. Onac, M. Veress, L. Piccini, and the other IJS reviewers who considerably helped me to organize and improve this paper.

\section{REFERENCES}

Allard P., Carbonnelle J., Métrich N., Loyer H. \& Zettwoog P., 1994 - Sulphur output and magma degassing budget of Stromboli volcano. Nature, 368: 326-330. http://dx.doi.org/10.1038/368326a0

Audra P., D'Antoni-Nobecourt J.-C. \& Bigot J.-Y., 2010 - Hypogenic caves in France. Speleogenesis and morphology of the cave systems. Bulletin de la Société Géologique de France, 181: 327-335.

http://dx.doi.org/10.2113/gssgfbull.181.4.327

Audra P., Mocochain L., Bigot J.Y. \& Nobécourt J.C., 2009 Hypogene cave patterns. In: Klimchouk A.B. \& Ford D.C. (Eds.) - Hypogene speleogenesis and karst hydrogeology of artesian basins. Ukrainian Institute of Speleology and Karstology, Special Paper 1, Simferopol: 17-22.

Baker C.K. \& Black P.M., 1980 - Assimilation and metamorphism at a basalt- limestone contact, Tokatoka, New Zealand. Mineralogical Magazine, 43: 797-807. http://dx.doi.org/10.1180/minmag.1980.043.330.15

Barker C.E. \& Bone Y., 1995 - The minimal response to contact metamorphism by the Devonian Buchan Caves Limestone, Buchan Rift, Victoria, Australia. Organic Geochemistry, 22-1: 151-164.

Battistini R., 1965 - Problèmes géomorphologiques de l'Extrême-Nord de Madagascar, Madagascar. Revue de Géographie, 7: 1-60.

Bayari C.S., Ozyurt N.N. \& Pekkans E., 2009 - Giant collapse structures formed by hypogenic karstification: the obruks of the Central Anatolia, Turkey. In: Klimchouk A.B. \& Ford D.C. (Eds.) - Hypogene speleogenesis and karst hydrogeology of artesian basins. Ukrainian Institute of Speleology and Karstology, Special Paper 1, Simferopol: 83-90.

Besairie H., 1973 - Précis de géologie malgache. Service géologique de Madagascar, Antananarivo, $141 \mathrm{p}$.

Cardellini C., Chiodini G., Caliro S., Frondini F., Avino R. Baldini A. \& Donnini M., $2011-\mathrm{CO}_{2}$ fluxes from Earth degassing in Italy. Geophysical Research Abstracts EGU General Assembly, 13, EGU2011-7778-1.

Courbon P. \& Chabert Cl., 1986 - Atlas des grandes cavités mondiales. International Union of Speleology, $255 \mathrm{p}$.

Cucciniello C., Melluso L., Morra V., Storey M., Rocco I., Franciosi L., Grifa C., Petrone C.M. \& Vincent M., 2011 - New ${ }^{40} \mathrm{Ar}-{ }^{39} \mathrm{Ar}$ ages and petrogenesis of the Massif d'Ambre volcano, northern Madagascar. Geological Society of America Special Papers, 478: 257-281. http://dx.doi.org/10.1130/2011.2478(14)

Decary R. \& Kiener A., 1970 - Les cavités souterraines à Madagascar. Annales de spéléologie, 25: 409-440.
Deegan F. M., Troll V. R., Freda C., Misiti V., Chadwick J. P., McLeod C. L. \& Davidson J. P., 2010 - Magmacarbonate interaction processes and associated $\mathrm{CO}_{2}$ release at Merapi Volcano, Indonesia: insights from experimental petrology. Journal of Petrology, 51-5: 1027-1051.

Demangeot J., 1963 - Karst et volcanisme en Italie centrale. Revue de géographie alpine, 51-2: 361-367.

Dubois C., Quinif Y., Baele J.-M., Barriquand L., Bini A., Bruxelles L., Dandurand G., Havron C., Kaufmann O., Lans B., Maire R., Martin J., Rodet J., Rowberry M.D., Tognini P. \& Vergari A., 2014 - The process of ghost-rock karstication and its role in the formation of cave systems. Earth-Science Reviews, 131: 116-148. http://dx.doi.org/10.1016/j.earscirev.2014.01.006

Ford D.C., 1989 - Features of the genesis of Jewel Cave and Wind Cave, Black Hills, South Dakota. National Speleological Society Bulletin, 51: 100-110.

Galdenzi S., 2009 - Hypogene caves in the Apennines (Italy). In: Klimchouk A.B. \& Ford D.C. (Eds.) Hypogene speleogenesis and karst hydrogeology of artesian basins. Ukrainian Institute of Speleology and Karstology, Special Paper 1, Simferopol: 101-116.

Gary M.O. \& Sharp J.M., 2006 - Volcanogenic karstification of Sistema Zacaton, Mexico. Geological Society of America, Special Paper 404: 79-89.

Gilli E., 2011 - Karstologie. Karsts, grottes et sources. Coll. Presup, Dunod, Paris, 244 p.

Gilli E., Chignoli M., Frèrejean J.M. \& Recoules A., 1981 - Madagascar, expéditions spéléologiques: Canopus 81 and Kelifefy 81, Spéléologie 115, Spéléo Club Martel, Club Alpin Français, Nice, 53 p.

Gunn J., 2004 - Encyclopedia of caves and karst science. Taylor \& Francis, New York, 902 p.

Hill C.A., 1987 - Geology of Carlsbad Cavern and other caves in the Guadalupe Mountains, New Mexico and Texas. New Mexico Bureau of Mines and Mineral Resources, 117, 170 p.

Iacono-Marziano G. \& Gaillard F., 2006 - Limestone assimilation: an important non magmatic source of volcanic $\mathrm{CO}_{2}$. Geophysical Research Abstracts, EGU meeting, 8, 08924 .

Iacono-Marziano G., Gaillard F. \& Pichavant M., 2007 - Limestone assimilation by basaltic magmas: an experimental re-assessment and application to Italian volcanoes. Contributions to Mineralogy and Petrology 155-6: 719-738. http://dx.doi.org/10.1007/s00410$\underline{007-0267-8}$

Joesten R. \& Van Horn S.R., 1999 - Numerical modeling of calcite coarsening in the contact aureoles of en echelon dikes: Analysis of the kinetic control of isograd geometry in contact metamorphism. In: Bjørn Jamtveit B. \& Meakin P. (Eds.) - Growth, Dissolution and Pattern Formation in Geosystems. Kluwer Academic Publishers: 109-141.

Karche J.P., 1972 - Contribution à l'étude géologique de la Montagne d'Ambre et des régions voisines du nord de Madagascar. Thèse de géol. univ. Besançon, $683 \mathrm{p}$.

Kjølle I., 2000 - Industrial mineral quality of limestone: the effect of contact metamorphism on textural properties, brightness and geochemistry. Norges geologiske undersøkelse Bulletin, 436: 85-91.

Klimchouk A.B., 1997 - The role of karst in the genesis of sulfur deposits, Pre-Carpathian region. Ukraine. Environmental Geology 31: 1-20. http://dx.doi.org/10.1007/s002540050158

Klimchouk A.B., 2004 - Speleogenesis: deep_seated and confined setting. In: Gunn J. (Ed.), Encyclopedia of caves and karst science: $1453-1458$. 
Klimchouk A.B. \& Ford D.C. (Eds.), 2009 - Hypogene speleogenesis and karst hydrogeology of artesian basins. Ukrainian Institute of Speleology and Karstology, Special Paper 1, Simferopol, 280 p.

Lesne P., Scaillet B., Pichavan M., Iacono-Marziano G. \& Beny J.M., 2011 - The $\mathrm{H}_{2} \mathrm{O}$ solubility of alkali basaltic melts: an experimental study. July Contributions to Mineralogy and Petrology, 162-1: 133-151.

Mahoney J., Nicollet C. \& Dupuy C., 1991 - Madagascar basalts: tracking oceanic and continental sources. Earth and Planetary Science Letters, 104: 350-363. http://dx.doi.org/10.1016/0012-821X(91)90215-4

Martín M., Diaz F., Galindo I., Salazar P., Salazar J., Hernández P. \& Pérez N., 2003 - Dinamic of diffuse $\mathrm{CO}_{2}$ degassing at the $\mathrm{NW}$ volcanic rift-zone of Tenerife, Canary Island, Eos Transactions, AGU, 84 (46), Fall Meeting Supplement, Abstract V21C-0542.

McGreevy J.P., 1982 - Hydrothermal alteration and earth surface rock weathering: a basalt example. Earth Surface Processes and Landforms, 7-2: 189-195. http://dx.doi.org/10.1002/esp.3290070211

Menichetti M., 2009 - Speleogenesis of the hypogenic caves in Central Italy. In: White, W.B. (Ed.), Proceedings of the $15^{\text {th }}$ International Congress of Speleology. Kerrville: National Speleological Society, 909-915.

Peyre J.-C., Arthaud G., Bessaguet D., Fulcrand S., Martin M., Radofilao J., Flandin J.-M. \& Tessier F., 1983 - Expédition spéléologique, Madagascar 1982. Spéléologie, Bulletin. Club Martel-Club Alpin Francais, Nice, 55 p.

Peyre J.-C., Bessaguet D., Curtarelli T., Franco E. \& Radofilao J., 1984 - Spécial Madagascar 1984, Spéléologie, Bulletin. Club Martel-Club Alpin Francais, Nice, 50 p.

Radofilao J., 1977 - Bilan des explorations spéléologiques dans l'Ankarana. Annales de l'Université de Madagascar. Série sciences naturelles et mathématiques, 14: 196-204.
Rakotosamizanany S., 2009 - Les gisements de corindons gemmes dans les basaltes alcalins et leurs enclaves. Signification pétrographique et métallogénique. Thèse Univ. Nancy et Antananarivo, 442 p.

Rossi G., 1973 - Problèmes morphologiques du karst de l'Ankarana, Madagascar. Revue de Géographie, 23: 61-90.

Rossi G., 1974 - Morphologie et évolution d'un karst en milieu tropical: l'Ankarana. Mémoires et Documents du CNRS, 14-II : 279-298.

Rossi G., 1980 - L'extrême-nord de Madagascar, Thèse Univ. Provence, Edisud, Aix-en Provence, 440 p.

Saint Ours J. de, 1958 - Étude géologique dans l'Extrêmenord de Madagascar et l'archipel des Comores. Thèse géol. univ. Strasbourg, Mémoires du Service géologique de Madagascar, Tananarive, $262 \mathrm{p}$.

Saint Ours J. de, 1959 - Les phénomènes karstiques à Madagascar. Annales de spéléologie, 14: 275-291.

Salomon J.-N., 2003 - Karst system response in volcanically and tectonically active regions. Zeits fur Geomorph. Suppl., 131: 89-112.

Salomon J.-N., 2009 - The tsingy karrenfields of Madagascar. In: Ginés et al. (Eds.), Karst rock features: Karren sculpturing. Postojna-Ljubljana, 411-422.

Siffre M., 1975 - Dans les abîmes de la terre, Flammarion, Paris, $304 \mathrm{p}$.

Veress M., Tóth G., Zentai Z. \& Schläffer R., 2009 - The Ankarana tsingy and its development. Carpathian Journal of Earth and Environmental Sciences, 4-1: 95-108.

Wallace P.-J., 2005 - Volatiles in subduction zone magmas: concentrations and fluxes based on melt inclusion and volcanic gas data. Journal of Volcanism and Geothermal Ressources, 140, 217-240.

Wilson J.M., 1987 - The Crocodile Caves of Ankarana: expedition to Northern Madagascar, 1986. Cave Science, 14 (3): 107-120. 